\title{
Does growth represent Chimera or Bellerophon for a family business? The role of entrepreneurial orientation and family influence nuances
}

Accepted for publication in European Management Review ()

\begin{abstract}
Growth brings lifeblood to sustain longevity across generation, but also critical challenges for family business. Relying on the behavioral agency model and its assumptions on risk-bearing in family firms, we discuss and test the effect of family involvement in the top management team (TMT) on family business growth. We use an input-behavior-outcome framework based on the mediating role of entrepreneurial orientation. We also consider the moderating role of different ownership structures on the relationship between family involvement in the TMT on entrepreneurial orientation (EO). Results based on survey data collected by the STEP research consortium support the hypothesized negative effect of family involvement in the TMT on growth, fully mediated by EO. We also find that the presence of passive family members as majority shareholders and multigenerational involvement in ownership are important contingencies of the direct effect. Our evidence points to the fact that risk-bearing in family firms is not just dependent on the degree of family involvement in management, but also on the interests of different types of shareholders. We show that the at-times stylized negative traits of family firms are not universally valid, and that a comprehensive view of family influence over the business is needed to ascertain whether and to what extent these firms actually achieve growth.
\end{abstract}

Keywords: Family business; growth; behavioral agency model; risk-bearing; entrepreneurial orientation.

\section{Introduction}

Growth is one of the most challenging concerns for family businesses striving to survive and succeed from generation to generation (Ingram et al., 2016; Naldi et al., 2007). Growth is particularly important in family firms, reflecting both business- and family-related interests, and may thus generate tensions (Ingram et al., 2016). Indeed, growth helps family firms pursue the business-oriented goal of sustaining a wealthy firm on one hand, and the family-oriented 
goal of sustaining and engaging the enterprising family across generations on the other hand. At the same time, a growth strategy may threaten the family need for liquidity and control over the business, so that some family businesses deliberately limit their growth (Gómez-Mejía et al., 2007, 2011; Hamelin, 2013). Metaphorically speaking, whereas for some family firms growth might epitomize Bellerophon, a hero of Greek mythology helping them deal with multiple challenges, for others it might embody Chimera, a monster causing disasters and harming the future of both the family and the business.

Extant literature has suggested that the decision to grow or harvest heavily depends on the degree of family influence over the business (Le Breton-Miller and Miller, 2008). However, there is contrasting evidence on the effect of family influence on growth (Backman and Palmberg, 2015; O’Boyle et al., 2012). Due to the family members' potential tendency to adopt conservative behaviors, the degree of family influence over the business may negatively affect the likelihood of growth in international markets (Sanchez-Bueno and Usero, 2014), sales and investment rates (Hamelin, 2013), and investments in R\&D, promotion, and other expenditures (Miller et al., 2011). Moreover, family influence has been shown to lead to lower growth rates, as family businesses, compared to other types of firms, tend to have difficulties in accessing the resources and capabilities needed to sustain their competitive advantage and grow (Croce and Martí, 2016; Sirmon and Hitt, 2003; Upton and Petty, 2000). Nevertheless, Chen et al. (2014) suggest that whereas family-controlled firms record lower sales growth rates, they are able to generate comparatively higher employment growth rates. Lee (2006) also reports a positive impact of family influence over the business on employment and revenue growth.

However, treating family firms as a homogeneous category might be constraining (Daspit et al., 2018). For example, with few exceptions, most studies on growth do not distinguish the role of family members as owners and/or managers, often assuming that the unification of ownership and control that characterizes family governance (Carney, 2005) unambiguously 
affects family business behaviors and strategic decisions. Among these exceptions, studies highlight that family involvement in the top management team (TMT) is particularly important in determining growth, as such involvement actually enforces the particular goals and priorities of the owners (Barbera and Hasso, 2013; Chrisman et al., 2018; Chua et al., 2011; Coad and Timmermans, 2014). Family involvement in the TMT is crucial for growth due to the critical role of top managers in strategic planning and execution (Chrisman et al., 2016; Upton et al., 2001), and their accountability for the effective implementation of strategic decisions (Chrisman et al., 2016; Guidice et al., 2013). If the role of family managers in shaping firms' behaviors and performance is indisputable, additional nuances of family involvement in ownership are invoked as measures to be used, together with managerial involvement, to capture the overall effect of family influence on firm performance (Chrisman et al., 2005; Garcia-Castro and Aguilera, 2014).

In this paper, we suggest three possible sources of heterogeneity in the family ownership structure - presence of non-family shareholders, passive family members as majority shareholders, multigenerational involvement in ownership - and combine them with family involvement in the TMT to study growth in family firms. In so doing, we offer a comprehensive and nuanced view of family influence over the business and its role in explaining firm growth. Moreover, research has long considered family influence on performance as a black box, thus limiting understanding the mechanisms intervening in such relationship, and ultimately, the growth process itself (Chrisman et al., 2016). We claim that entrepreneurial orientation (EO), a well-known antecedent of growth (Casillas and Moreno, 2010; Rauch et al., 2009), is a good candidate to explain how different forms of family involvement lead to growth. We thus theorize and test an input-behavior-outcome relationship where the input is the form of family involvement in management and ownership structure, behavior is the entrepreneurial orientation, and outcome is family business growth. We then use this model to address the 
following research question: Under which conditions and how does family involvement in the TMT affect growth in family business?

The behavioral agency model (BAM) (Wiseman and Gómez-Mejía, 1998) underpins the development of our model. In particular, we use the different motives guiding strategic decision-making in family firms at different degrees of family involvement in the TMT to explain firm growth. In addition, we take into account how non-family shareholders, passive family members as shareholders, and owners from different generations actually differ in terms of risk-bearing, i.e. perceived wealth-at-risk (Hoskisson et al., 2017; Wiseman and GómezMejía, 1998), thus hindering or strengthening the effect of family involvement in management.

We test our model via structural equation modeling on a unique sample of 645 family firms derived from the first worldwide double-respondent STEP (Successful Transgenerational Entrepreneurship Practices) survey, launched by 48 universities affiliated with the STEP project and completed in 2015. The findings show that different 'nuances' (Daspit et al., 2018: 294) of family influence have to be considered to fully grasp the effect on family firm growth. Indeed, while family involvement in the TMT has a negative effect on firm growth (fully mediated by EO), this relationship is attenuated by the presence of passive family members as major shareholders, and strengthened by the presence of multiple generations in ownership. We find, instead, no significant moderating effect for the presence of non-family shareholders.

Overall, these findings contribute to the ongoing debate on the relationship between family involvement, governance, and family firm performance (Daspit et al., 2018) through the inputbehavior-outcome model that offers a comprehensive picture of the phenomenon on a global sample of family firms. In addition, our study advances the importance of EO as the mechanism that renders family involvement an effective determinant of family firm growth (Casillas and Moreno, 2010; Covin et al., 2006; Moreno and Casillas, 2008). Implications for theory and practice are also offered. In particular, this model suggests that BAM predictions depend on 
the interests of different types of family shareholders, i.e. passive family members as major shareholders, and family shareholders belonging to different generations (e.g., Fattoum-Guedri et al., 2018). Practitioners should also carefully consider our model's predictions to fine-tune the ownership and management structure in the family firm so as to foster entrepreneurial orientation and growth.

\section{Theoretical background and hypothesis development}

\section{Behavioral agency model and family firm growth}

Although several theoretical perspectives have been adopted to discuss growth in family firms (e.g., agency theory, stewardship theory, resource based view), the behavioral agency model which specifically focuses on a dynamic view of firms' risk-bearing according to the framing of situations as gains or losses with respect to a specific reference point (Wiseman and GómezMejía, 1998) - can actually shed light on the effect of family involvement in the TMT and different forms of ownership structure on family firm growth (Gómez-Mejía et al., 2011). According to the BAM, decision-making processes are influenced by the reference point of the firm's principals, namely, in the case of family firms, the need to protect the affective and financial endowment of family members (Gómez-Mejía et al., 2007, 2010, 2011; Le BretonMiller and Miller, 2013). Family members in the firm may indeed perceive themselves as 'family nurturers' and conceive the business as a source of stable and secure income for the family, which has to be protected (Miller et al., 2011). Additionally, in family firms, socioemotional motives are also relevant in guiding decisions: family members' desire to exercise authority, enjoyment of family influence, maintenance of clan membership within the firm, appointment of trusted family members to important positions, retention of a strong family identity, and continuity of the family dynasty, are some of the socioemotional motives guiding family business decision-making and behavior (Berrone et al., 2012; Gómez-Mejía et al., 2007). 
Based on these elements, BAM suggests that, ceteris paribus, family members who control the business are likely to adopt a conservative strategy, and tend to be more loss averse compared to, for example, single-owner founders (Miller et al., 2011). Managerial choices in family business are thus "driven by a desire to preserve and enhance the family's socioemotional wealth apart from efficiency or economic instrumentality considerations" (Gómez-Mejía et al., 2011: 656). In sum, building on BAM assumptions, family firms' decisions are dependent on the achievement of outcomes - such as growth - that can, on the one hand, guarantee their flourishment and family sustainment over generations, and on the other, threaten socioemotional endowments such as control over the business and family members' identification with it (Gómez-Mejía et al., 2007; Wiseman and Gómez-Mejía, 1998).

We develop our hypotheses on the direct effect of family involvement in the TMT on both family firm growth and EO. We then discuss the mediating role of EO, and finally, the moderating effect of different ownership structures. Our model thus includes family involvement in the TMT, different facets of the ownership structure (i.e. presence of nonfamily shareholders, passive family members as majority shareholders, and multigenerational involvement in ownership), and an attitudinal and behavioral mechanism (i.e. EO), leading to or preventing a family firm outcome (i.e. family business growth). In particular, the use of EO as mediator between family involvement in the business and growth allows us to go beyond an input-outcome relationship, and enriches our model with more explanatory power.

\section{Family involvement in TMT and family firm growth}

When family members are involved in key decision-making processes, such as those leading to growth, socioemotional wealth is likely to become the primary frame of reference in the management of the family firm (Hoskisson et al., 2017). Financial motives (e.g., compensation, external career advancement, internal resource allocation), which represent an incentive for managers to embrace growth strategies, are weaker in this context. Gómez-Mejía et al. (2011: 
678), for example, argue that "monetary quid pro quo expectations do not loom as large for family executives who are emotionally attached to the firm, and they are therefore more likely to accept a lower remuneration in exchange for 'psychic rewards', including the 'security blanket' provided by the family". Moreover, family managers are less likely to take advantage of the external labor market for executives that highly value the pursuit of growth strategies, tending to build their career within the family business, whose internal market does not necessarily reward growth (De Massis et al., 2013; Gómez-Mejía et al., 2011).

Socioemotional motives (e.g., need for control and long-term orientation) are instead highly relevant in influencing family managers' risk-bearing, and hence, decision-making in a growth prospect. First, family managers tend to develop a close attachment to the firm so that their abilities "to exercise authority and control over the business represent an important source of emotional satisfaction" (Gómez-Mejía et al., 2011: 655). Growth strategies may require to or have the effect of diluting the level of control that the family exercises over business decisions. Hence, family members in key managerial positions will rather avoid engaging in decisions that put their socioemotional wealth endowment at stake and thus inherently limit family business growth (Casillas et al., 2010). Second, family members in the firm are likely to give priority to the desire to perpetuate the business for future generations, hence focusing on firm survival rather than on maximizing financial wealth (Steier, 2003), with a possible detrimental effect on firm growth (Hamelin, 2013). In the eyes of family members, the affective, emotional, and social aspects related to the business represent the wealth to be protected in the pursuit of a long-lived business at the cost of firm growth (Gómez-Mejía et al., 2007).

Family firms and family managers are not all alike (Chrisman et al., 2016). Hence, the specific weight of and the balance between financial and socioemotional motives might vary substantially across family firms (De Massis et al., 2018). However, the extent to which family members are present and influential in the TMT will - ceteris paribus - determine a substantial 
convergence towards a prevalence of socioemotional motives, through shared values, identification and experiences. Additionally, higher influence given by higher involvement in the TMT will also provide family members the power to pursue such non-economic motives.

In sum, our baseline hypothesis is that the priority will be given to socioemotional over financial motives at higher level of family involvement in the TMT, and this will have an impact on firm strategies and limit growth. Hence:

Hypothesis 1. The higher the family involvement in the TMT, the lower the family firm growth.

\section{Family involvement in the TMT and EO}

Family involvement in the TMT, we argue, also plays an important role with respect to EO, especially in relation to growth (e.g., Casillas and Moreno, 2010). Family members in leading positions might avoid the risks specifically associated with entrepreneurial strategies (i.e., risk aversion), as a consequence of prioritizing family wealth protection (i.e., risk-bearing) (Naldi et al., 2007; Zellweger and Sieger, 2012). Indeed, the accumulation of family wealth over time represents an endowment that family members do not want to lose by engaging in new ventures or other entrepreneurial strategies. In particular, in the attempt to avoid any losses to the family's wealth, family members might remain anchored to past strategies and established routines. Path dependence in strategic decision-making can constrain the leader's opportunity to engage in innovation (e.g., Salvato et al., 2010), and more generally, to develop an EO attitude in the family business (Pittino et al., 2017). This might be due to the propensity of some family members to create a business culture characterized by inflexibility and resistance to change, and hence more easily controlled by the family (Hall et al., 2001). Eventually, such organizational inertia paralyzes any entrepreneurial endeavors. Moreover, the avoidance of risky strategies might be due to family members' psychological ownership, which - through 
knowledge sharing and cohesive socialization - would intensify their concern for socioemotional wealth protection, ultimately resulting in a lower level of entrepreneurial behavior (Pittino et al., 2018). Like above, we advance that the higher such involvement, the stronger is the weight of socioemotional motives in the firm as well as the ability of family members to guide decision making according to such principle (hence reducing EO). In light of the foregoing, we propose:

Hypothesis 2. The higher the family involvement in the TMT, the lower the family firm EO.

\section{The mediating role of $E O$}

Considering the direct effect of family involvement in the TMT on both family firm growth and EO discussed above, and the well-known role of EO on growth (Moreno and Casillas, 2008), we argue that EO acts as mediator for the relationship between family involvement in the TMT and growth. EO can be considered the result of attitudes and behaviors adopted by individuals in the organization, particularly those involved in decision-making processes (Miller and Le Breton-Miller, 2011; Pittino et al., 2018). Most research, moreover, has shown a positive relationship between EO and growth (e.g., Casillas and Moreno, 2010; Rauch et al., 2009). In our model, EO is thus conceived as the key behavioral mechanism driving (or hindering) family business growth (Covin et al., 2006). In other words, we argue that family firm growth can be nourished only by fostering an entrepreneurial (i.e, risk-taking, proactive and innovative) posture (Stenholm et al., 2016).

In sum, it is plausible to consider EO as the mechanism that intervenes in the hypothesized negative relationship between family involvement in the TMT and firm growth. Therefore, we propose: 
Hypothesis 3. EO mediates the negative relationship between the degree of family involvement in the TMT and family firm growth.

\section{The moderating role of the ownership structure}

While family involvement is usually used as a blurred label describing the presence of family members in either ownership or management, or both, we here suggest disentangling the effects of the different forms of family influence over the business so as to isolate their unique contribution to EO, and thus firm growth. In particular, in line with Miller and Le Breton-Miller (2006: 79), we claim that "it is important to distinguish between two types of family involvement: service on the top management team and ownership". Whereas in the previous hypotheses we discuss the effect of the former on growth through EO, we here focus on how different ownership structures affect such relationship. The role of family dynamics and firm ownership structure in shaping the family firm's entrepreneurial orientation has recently received increased attention (Brumana et al., 2017; McKelvie et al., 2014; Minola et al., 2016).

With our subsequent hypotheses, we suggest that the heterogeneous interests of different types of owners could affect (attenuate or exacerbate) the managers' risk-bearing associated to socioemotional motives when pursuing entrepreneurial strategies. This will translate into a different (higher or lower) effect of family involvement in TMT on EO. There are at least three sources of heterogeneity in family ownership structure that, we argue, are worth considering in relation to family firm growth: presence of non-family shareholders, passive family members as majority shareholders, and multigenerational involvement in ownership.

First, we argue that the presence of non-family shareholders might favor financial over socioemotional motives with consequences on EO. Such shareholders might contribute to the family business by providing expertise and objectivity, alternative perspectives, and critical information that the family might overlook. Non-family shareholders "can also serve as more objective monitors of family executives, help in locating and hiring better managers, improve 
resource-allocation decisions, and avoid expropriation of firm wealth by family members" (Miller and Le Breton-Miller, 2006: 75). Gómez-Mejía et al. (2003), for example, find that the presence of institutional owners decreases the likelihood of family CEO's awarding firm stocks, giving such CEOs more power to pursue the family rather than the business agenda. Similarly, Gómez-Mejía et al. (2011) show that the negative relationship between family involvement and $\mathrm{R} \& \mathrm{D}$ expenses tends to be moderated by the presence of institutional investors in the ownership structure of the firm, so that increasing institutional investor ownership weakens this relationship.

This leads, we argue, to a moderating effect that weakens the negative impact of family involvement in the TMT on EO because the presence of non-family shareholders will attenuate the managers' risk-bearing associated to socioemotional motives when pursuing entrepreneurial strategies. Therefore, we propose:

Hypothesis 4a. The presence of non-family shareholders moderates the relationship between family involvement in the TMT and EO, such that family involvement in the TMTEO path is weakened with non-family shareholders.

Second, we suggest a distinction between the interests of family owner-managers and other family owners, such as passive family members (i.e. not involved in the firm's management) who are shareholders of the family firm, as relevant to explaining family firm behavior and performance (González et al., 2014; Michiels et al., 2015; Schulze et al., 2003). In line with BAM tenets, the presence of passive family members in the ownership structure of the family firm is likely to lead to particular interests that alter the balance between socioemotional and financial motives characterizing family firms. We argue that passive family members who are shareholders of the family firm, while not extraneous to the active family members' concerns for the preservation of socioemotional wealth, also have a strong concern for financial 
remuneration (e.g., they often prefer to receive dividends instead of reinvesting cash in the firm; see Michiels et al., 2015). They will thus influence the decisions made in the business by, for instance, appointing members to the board of directors who would guarantee that financial motives drive the strategic decisions (Basco and Calabrò, 2017). Active owners, similarly to passive ones, are interested in obtaining dividends from their capital investment in the family business. However, they have much more than their financial wealth at stake: the emotional attachment to the firm, their professional future in it, and potentially the careers of their heirs depend on the firm's survival (i.e. their socioemotional wealth).

The result is a moderating effect that weakens the negative impact of family involvement in the TMT on EO because the presence of passive family shareholders will attenuate the managers' risk-bearing associated to socioemotional motives when pursuing entrepreneurial strategies. Therefore, we propose:

Hypothesis $\mathbf{4 b}$. The presence of passive family members as major shareholders moderates the relationship between family involvement in the TMT and EO, such that family involvement in the TMT-EO path is weakened with a majority of passive family members as shareholders.

Third, the debate on family firm growth has also been nurtured by studies focusing on the role of generational involvement (Eddleston et al., 2013; Sciascia et al., 2014). We argue that the presence of multiple generation representatives in the ownership structure of the family firm moderates family involvement in the TMT-EO relationship, further strengthening such negative relationship. In particular, even more conservative growth behavior is expected compared to the absence of ownership dispersion among generations. The fact that part of the company's equity has already been transferred from one generation to the next, and both simultaneously involved in the firm's ownership structure, activates the mechanism of 
generational shadow (Davis and Harveston, 1999), or confining legacy (Kelly et al., 2000), that is, the influence of the prior generation (and especially the founder) on the business. The presence of the prior generation, we claim, pushes the next generation to embrace and defend the values and motives of their predecessors in the attempt to gain legitimacy and acquire knowledge (Cabrera-Suárez et al., 2001). It is for this reason that managers' risk-bearing associated with socioemotional motives becomes even more important in such ownership structure - "multi-generation family firms may exhibit an organization-serving culture and a focus on nonfinancial objectives" (Westhead and Howorth, 2006: 304). In light of the foregoing, we posit:

Hypothesis 4c. Multigenerational involvement in ownership moderates the relationship between family involvement in the TMT and EO, such that the family involvement in TMTEO path is strengthened with multigenerational involvement in ownership.

\section{Methodology}

\section{Sample and data collection}

Data were gathered through the STEP Survey, launched and compiled from September 2014 to February 2015 by family firms from 35 countries. The survey was administered by the 48 universities affiliated with the STEP project around the world. The STEP project examines how families generate new economic activities through venturing and renewal across generations. The criteria for selecting family firms to participate in the survey were the following: (i) a family should hold the largest or dominant block of voting shares; (ii) the family firm should at least be in the second generation; and (iii) the family business should be among the most important players in the industry in which it operates.

The questionnaire was designed by the STEP consortium using previously validated scales and the experience of the research team in conducting qualitative research for more than 10 
years on the specific topic of transgenerational family firms, namely, family firms that successfully develop across generations thanks to their entrepreneurial mindset (Habbershon et al., 2010). A pilot test of the survey instrument was conducted between June and July 2014. The results of the pilot test were used to make modifications to the questionnaire and obtain the final survey instrument. The survey was written in English and offered in 12 languages (Spanish, German, Simplified and Traditional Chinese, Dutch, Thai, Swedish, Russian, Italian, Brazilian Portuguese, French, and Japanese). For all languages, a professional translation service was used. The survey contained four blocks: general information, respondent information, family business group level information (performance dimensions), and primary company level information (EO, family resources, family involvement, family life cycle stages, business environment, industry).

The survey assessed successful family business transgenerational practices in Asia, Europe, Latin America, and North America. The multi-respondent methodology - namely, two members from each participating family business - increased the accuracy of the data and reduced potential common method variance (e.g., Foss et al., 2013; Holt et al., 2017). 1,056 participants from 686 family firms compiled the questionnaire, a response rate of 27\% (STEP, 2015). Omitting all observations with missing values on the relevant variables, for this study we used a final sample of 587 observations, which includes 306 with single-respondent and 281 with double-respondent family firms (for a total of 868 completed questionnaires). We aggregated the observations deriving from double-respondent cases using a shared composition model, in line with research investigating the extent to which assessments are shared across family members and generations (Chandler, 2015; Holt et al., 2017). In particular, we evaluated the average interrater agreement, which equals 0.79 , thus greater than the usually accepted threshold of 0.7 (Klein and Kozlowski, 2000), allowing to create a unique score (calculated with the mean of the two family members' responses to the Likert scales on growth). The final 
587 sampled firms are distributed in four main global regions: Asian-Pacific with 49 family firms, Europe with 285 family firms, Latin America with 91 firms, and North America with 162 firms. The average family firm is 52 years old and has 765 employees.

\section{Variables}

Dependent and mediating variables. Growth is a multidimensional construct measured in the STEP survey through four items, namely, growth in sales, growth in market share, growth in employees, and growth in profitability. The choice of using subjective, self-reported measures is based on extant research investigating growth in family business (Eddleston and Kellermanns, 2007; Eddleston et al., 2013). In line with existing studies, all items were rated on a scale from 1 (much worse) to 5 (much better), as respondents were asked about their current performance with respect to competitors in the previous three years $(2011,2012,2013)$. Scholars have found that these perception-based measures are correlated with objective data (Ling and Kellermanns, 2010).

We measure entrepreneurial orientation with a 10-item Likert scale, anchored to 1-5, encompassing the dimensions of risk-taking, proactiveness, innovativeness, autonomy, and competitive aggressiveness (Lumpkin and Dess, 1996, 2001; Rauch et al., 2009). This construct was proxied with 15 indicators in the survey. However, five were eliminated, as an exploratory factor analysis showed that these omitted items reduced the explained variance. In the Appendix we report the retained items and Cronbach's alpha for the respective variables.

Independent and moderating variables. We account for family involvement in the TMT to measure the extent to which the family contributes to decision-making (Chrisman et al., 2012; Miller and Le Breton-Miller, 2006). We thus evaluate the TMT family ratio, a continuous variable measuring the percentage of family members over the size of the TMT (e.g., Cruz et al., 2010). 
We include three moderators to assess the contingent role of heterogeneity in the ownership structure, namely, presence of non-family shareholders, passive family members as major shareholders, and multigenerational involvement in ownership. The first accounts for the presence of non-family shareholders whose interests often differ from family shareholders, and may suffer from potential expropriation (e.g., Burkart et al., 2003; Young et al., 2008). We operationalize this variable with a dummy variable that takes value 1 when there are non-family shareholders in the ownership structure, and 0 otherwise. The second, instead, is intended to grasp the weight of passive family members in the ownership structure, namely, family members not employed by the family business and who usually have incongruent interests with respect to family members active in the family business. The former usually expect to receive dividends, while the latter prefer to reinvest cash in the firm (Michiels et al., 2015; Schulze et $a l ., 2003)$. We operationalize this variable with a dummy that takes value 1 when the percentage of shares owned by passive family members is above the threshold of $50 \%$, and 0 otherwise. Finally, multigenerational involvement in ownership accounts for the simultaneous presence of multiple generations in the ownership group, capturing the degree to which multiple generations are involved in ownership and control of the family firm (Eddleston et al., 2008; Kellermanns et al., 2012). This dimension is measured with a dummy variable that takes value 1 if two or more generations are simultaneously represented in the ownership group, and 0 otherwise. The interaction effects were obtained by multiplying the independent variables with the respective dummy variable, after standardizing the original interacting variables.

Control variables. We included a set of control variables that can directly affect firm growth. First, we accounted for firm size and age. The former is considered significant, as extant research has shown that firm size captures possible economies or diseconomies of scale and entry barriers (e.g., Hamelin, 2013), and relates to organizational inertia as well as difficulty in processing information regarding, for example, the available and needed resources (e.g., Ling 
and Kellermanns, 2010). The corresponding variable is equal to the number of full-time employees, as reported by the survey respondents (O'Boyle et al., 2012). Firm age, measured as the number of years since the family has owned the firm (e.g., Covin et al., 2006), can favor growth due to the decreasing liability of newness associated with more mature firms (e.g., Eddleston et al., 2013). However, firm age might also be associated with institutionalized routines and norms that, in turn, hamper growth (e.g., Ling and Kellermanns, 2010). We controlled for geographic location, as the STEP database is based on a world-wide survey. In particular, we created four dummies, i.e. Asia, Europe, Latin America, and North America (e.g., Zellweger et al., 2011), as there might be differences in terms of how institutional regulations, as well as cultural and political issues, affect growth in different regions of the world (e.g., Chen et al., 2014). Moreover, we considered the industrial sector where these firms operate. In particular, we created a dummy variable that takes value 1 if the firm mostly operates in the manufacturing industry, and 0 otherwise (e.g., Sciascia and Mazzola, 2008). Finally, we accounted for the extent of profits to reinvest, as these might foster growth (Molly et al., 2012). In addition, growth might depend on strong relationships within the organization and collaborative relationships with customers; indeed, autonomy from internal and external stakeholders might be deleterious to growth (Casillas and Moreno, 2010). These dimensions are proxied with three items that measure the extent to which respondents perceive their firms can rely on these resources, with scales anchored at 1 ("not at all") to 5 ("a great deal").

\section{Data analysis}

We tested the hypotheses using partial least squares structural equation modeling (PLS-SEM). This is a variance-based method acknowledged as particularly suitable for research in strategic management (Hair et al., 2012), and especially family business (Sarstedt et al., 2014), as it allows explicitly incorporating measurement errors into models, and simultaneously studying multiple relationships among the independent and dependent constructs under investigation. In 
addition, it is the most reliable approach to test mediating relationships among constructs, especially when multiple items are included to capture each construct (e.g., Iacobucci et al., 2007).

\section{Results}

The analysis of the results includes two stages, as recommended and practically applied in extant research (e.g., Anderson and Gerbing, 1988; Eddleston and Kellermanns, 2007). We assess, first, the validity of the measurement model, and after presenting the descriptive statistics, report the results of the tests, thus assessing the structural model, with a particular focus on the mediating effect of EO.

\section{Measurement model}

The assessment of the measurement model follows the recommendations of Hair et al. (2012), including the reliability of items, internal consistency, and construct validity, i.e. convergent validity and discriminant validity. First, as shown in Table 1, we report the composite reliability (CR) of all constructs, the average variance extracted (AVE), item loadings, and t-values (twotail test) of the respective loadings.

------ Insert Table 1 about here ------

The factor loadings range from 0.42 to 0.902 , thus exceeding the recommended threshold of 0.4 (Ford et al., 1986; Hair et al., 2016). CR is acceptable for both growth and EO constructs (threshold equals 0.7), whereas AVE satisfies the criterion of minimum 0.50 (Fornell and Larcker, 1981) only for growth. The low level of AVE for the EO construct might depend on the development of the scale integrating the items for the different dimensions of EO (i.e. risktaking, proactiveness, innovativeness, autonomy, and competitive aggressiveness). Nevertheless, as all factor loadings are significant, albeit some lower than 0.5 , we considered 
any covariance between the errors of the measurement model. We thus evaluated the modification indices, which provide important information on omitted paths in the fitted model (Steiger, 1990). This procedure suggested including in the measurement model the covariance of items EO_1 and EO_2, items EO_3 and EO_4, items EO_7 and EO_8, items EO_9 and EO_10. We assessed the significance of this analysis, using a chi-square statistic $(\chi 2)$, obtained by dividing $\chi^{2}$ by the degrees of freedom, the comparative fit index $(\mathrm{CFI}>0.9)$, the TuckerLewis index (TLI > 0.9), and the root mean square error of approximation (RMSEA $<0.08$ ), in line with the recommendations of Bagozzi and Yi (1988). Consequently, we assessed the fit of the whole model, finding that the usually accepted criteria $(\chi 2 /$ d.f. $<3)$, CFI and TLI $>0.9$, RMSEA $<0.08$ are all satisfied (see Table 2 ).

Discriminant validity is assessed by comparing the squared correlation between two constructs with their respective AVEs (Fornell and Larcker, 1981). All the squared correlations were lower than the AVEs, indicating discriminant validity, as shown in Table 2.

------ Insert Table 2 about here ------

Moreover, we assessed discriminant validity through the heterotrait-monotrait (HTMT) ratio of correlation, which equals 0.44 , below the usually accepted thresholds of 0.85 and 0.9 (Henseler et al., 2015).

\section{Structural model - hypothesis testing}

Table 3 presents the descriptive statistics and correlations for all the variables used in this study. In particular, significant differences among world regions emerge, particularly when comparing growth in Latin American and European family firms with respect to Asian firms. In addition, slightly significant differences emerge across world regions with respect to entrepreneurial orientation (Basco et al., 2018). Furthermore, the extent of profits to reinvest 
and collaborative relationships with customers is positively significant both for growth and for EO.

------ Insert Table 3 about here ------

Tables 4 and 5, and Figure 1 present the structural model results showing the tests of our hypothesized relationships. H1 is supported, as family involvement in the TMT negatively relates to growth $(\beta=-0.149 \mathrm{p}<0.001)$ (see Table 4$)$.

------ Insert Table 4 \& 5 about here ------

------ Insert Figure 1 about here ------

As shown in Table 5, when we include the mediation of EO and the moderation of the presence of non-family shareholders, passive family members as major shareholders, and multigenerational involvement in ownership, we find evidence that TMT family involvement significantly and negatively affects EO $(\beta=-0.153, \mathrm{p}<0.001)$, thus supporting H2. Following the recommendations of Hayes (2009) and Preacher et al. (2007), we considered the conditional indirect effect of family involvement in the TMT on family firm growth, through EO, at values of the moderators to assess the effect of the moderated mediation.

Mediation test. $\mathrm{H} 3$ predicts the significant role of $\mathrm{EO}$ as mediator in the relationship between family involvement in the TMT and family firm growth. First, including the mediator construct, we find that the negative effect of family involvement in the TMT on EO is counterbalanced by the strong and significant relationship between EO and family firm growth $(\beta=0.319, p<$ 0.001). The indirect effect of family involvement in the TMT via the mediator EO on family firm growth is $-0.108(\mathrm{p}<0.001)$, thus much less negative. At the same time, in the moderated mediation model, the relationship between family involvement in the TMT and family firm growth is no longer significant, thus suggesting that EO fully mediates this relationship. 
Moderation tests. As regards the moderation of ownership structures as developed in H4a, $\mathrm{H} 4 \mathrm{~b}$, and $\mathrm{H} 4 \mathrm{c}$, we find evidence for the positive effect of passive family members as major shareholders $(\beta=0.081 \mathrm{p}<0.10)$, and a negative effect of multigenerational involvement in ownership $(\beta=-0.083 \mathrm{p}<0.05)$ on the relationship tested in $\mathrm{H} 2$. These results support $\mathrm{H} 4 \mathrm{~b}$ and $\mathrm{H} 4 \mathrm{c}$, while we find no evidence in support of $\mathrm{H} 4 \mathrm{a}$ regarding the moderating effect of the presence of non-family shareholders.

In addition, we compute the conditional indirect effect and its standard errors through a nonlinear combination of estimators, and then bootstrap them to compute the respective confidence intervals (Hayes, 2015). In particular, the conditional indirect effect is obtained by multiplying the coefficient from the structural equation model along with selected values of the moderators. We use three different values of the moderators for passive family members as major shareholders and multigenerational involvement in ownership: mean -1 s.d. (low moderator), mean (medium moderator), and mean +1 s.d. (high moderator). We find that the conditional indirect effect for the relationship between family involvement in the TMT and growth increases as the value of multigenerational involvement in ownership increases, while decreasing as the value of passive family members as major shareholders increases, in both cases taking into account the effect mediated by EO at the three values of the moderator.

\section{Robustness checks}

We subjected the above results to sensitivity tests. First, although common method variance should not be a critical issue given the use of double-respondent survey data (Holt et al., 2017), following the recommendations of Williams et al. (2010), we additionally used a CFA marker technique to test whether this is an issue in our model. We identified Family Life as the marker variable. Family Life is a latent variable with five indicators (Likert scales anchored to 1-5), i.e. help when troubled, discussion and problem sharing, accepts/supports new directions, expresses affection, and spending time together (Smilkstein et al., 1982). The comparison 
between the unconstrained (U-Model) and constrained model (R-Model) is not significant ( $\mathrm{p}$ > 0.1), suggesting that common method bias is not an issue in this study. Second, we considered the special features of the database that includes observations from two respondents who are both knowledgeable about the strategic issues relevant to their family business. Thus, we tested the model only on the subsample of observations obtained from double-respondent family firms, and found similar results regarding the effect of family involvement in the TMT on growth mediated by EO. Then we tested the model on the single items that constitute the growth latent variable, i.e. growth in sales, growth in market shares, growth in employees, and growth in profitability. In all four regression models, the negative effect of family involvement in the TMT, the mediating role of EO, the positive moderation of passive family members as major shareholders, and the negative moderating role of multigenerational involvement in ownership are supported. As regards the presence of publicly listed firms in our sample, we replicated the analyses removing listed family firms, obtaining analogous results $(\mathrm{CFI}=0.948, \mathrm{TLI}=0.938$, RMSEA $\left.=0.035, \mathrm{R}^{2}=0.23\right)$. Moreover, we changed the proxies adopted for the moderators. Indeed, we considered the possibility that the presence of non-family shareholders might be effective with respect to EO and growth if they own at least 5 or $10 \%$ of shares, thus representing blockholders in the family firm ownership structure. Nevertheless, the results are consistent and we found no moderation on the relationship between family involvement in the TMT and growth. Moreover, we found analogous results when we relaxed the assumption of a majority of passive family shareholders: building the dummy variable using a threshold equal to $45 \%$, we obtain similar results.

Finally, we followed the recommendations of Hult et al. (2018) to take into account any endogeneity issues. Since we have an explanatory model, we need to ensure that endogeneity is not a critical issue (Stage 1). Hult et al. (2018) also suggest checking whether endogeneity issues are identified in related prior research (Stage 2), a quite relevant issue as discussed in 
some studies that consider reverse causality as a potential endogeneity concern (e.g., Eddleston et al., 2013). In Stage 3, they suggest including control variables that are theoretically linked to the potential endogenous variables. Thus, we used a two-stage least squares estimation technique to ensure that family involvement in the TMT and growth do not suffer from endogeneity, selecting two instrumental variables correlated with the independent variable, but uncorrelated with the error term. From the STEP survey we identified the voting rights held by family members who are active in the firm's management and the number of shareholders in the TMT, which are not correlated with growth. Indeed, there is evidence that family control may be enhanced by the adoption of governance mechanisms, such as dual class shares, thus suggesting focusing on voting rights (Klein et al., 2005). In addition, owner-managers have substantial discretionary power (Ben-Amar and André, 2006), and their presence might ensure family control through appointing family members in the TMT. We first tested the effect of the instruments on family involvement in the TMT $\left(\beta=0.003 p<0.001\right.$ and $\beta=0.02 p<0.05, R^{2}$ $=0.11)$. In the second step, we found analogous results $(\mathrm{CFI}=0.955, \mathrm{TLI}=0.947, \mathrm{RMSEA}=$ $0.032, R^{2}=0.22$ ), thus ensuring the robustness of results against potential endogeneity issues.

\section{Discussion and Conclusion}

Our findings suggest a negative effect of family involvement in the TMT on family firm growth and EO, with EO mediating the first relationship. While the presence of non-family shareholders does not significantly affect the relationship between family involvement in the TMT and EO, the presence of passive family members as major shareholders and multigenerational involvement in ownership play a significant moderating role. In particular, whereas passive family members as major shareholders weaken the negative link between family involvement in the TMT and EO, multigenerational involvement in ownership has a strengthening effect. 
The discussion from these findings is particularly compelling to shed light on the tensions associated with growing the family business (Ingram et al., 2016), suggesting that we cannot easily answer the dilemma of whether growth represents Chimera or Bellerophon for family businesses. Indeed, our results highlight that the effect of family influence over the business on growth is not univocal, and the different forms of family members' involvement in management and ownership have to be taken into account (Chrisman et al., 2018; Daspit et al., 2018). When considering the relative weight of family members with respect to non-family members in the TMT, the rationale based on the idea that socioemotional wealth is at stake is supported by the data with a significant detrimental effect on growth (H1). Hindrance to growth can thus be associated with a prevalence of family members in the TMT, a condition that the literature has linked to the choice of conservative strategies that reflect the fear of losing familyrelated rewards linked to the wealth that the family accumulates in a unique under-diversified business (Belenzon et al., 2016; Hamelin, 2013; Sanchez-Bueno and Usero, 2014). In other words, family managerial involvement generates a "tendency toward careful resource conservation and allocation relative to other governance modes" (Carney, 2005: 254).

Concerning EO, the negative effect of family involvement in the TMT on EO (H2) supports our arguments suggesting that family managers would avoid putting the family wealth at stake (e.g., Naldi et al., 2013), and instead show a tendency toward path dependence and organizational inertia (e.g., Salvato et al., 2010), and high levels of psychological ownership (Pittino et al., 2018). Moreover, the support found for the mediating role of EO (H3) suggests that this behavioral dimension can actually be considered the key element leading family firms to grow by reducing their reliance on conservative strategies (Hamelin, 2013). Our findings support the idea advanced by Covin et al. (2006) that "EO is essentially a growth orientation" (p. 71). Interestingly, although the presence of family members in the TMT is detrimental to developing an entrepreneurial attitude in the organization (Pittino et al., 2018), when this 
orientation is nonetheless present as a characteristic of the family business, it is conducive to growth (Rauch et al., 2009). However, given the negative indirect effect, family involvement dampens the positive effect of EO, in line with the findings of Naldi et al. (2007).

The intertwinement between involvement in management and ownership adds additional nuances to this discussion, offering further insights on family firm heterogeneity (Daspit et al., 2018). As theorized in H4a-c, the role of ownership deserves particular attention, as our moderated mediation suggests that the diverging interests of different types of shareholders affect the conditions under which socioemotional rather than financial motives lead family managers to foster or hinder an entrepreneurial orientation, which, in turn, influences the strategic outcomes, such as growth. We find that passive family members as major shareholders concerned about financial rewards (e.g., dividends) and socioemotional wealth protection (Michiels et al., 2015) can reduce the negative effect of family involvement in the TMT on EO and growth. Instead, multigenerational involvement in ownership might lead to enacting a confining legacy that further supports the prioritization of socioemotional motives of family managers (Miller and Le Breton-Miller, 2006; Westhead and Howorth, 2006), thus strengthening the negative effect on EO and growth. These differences, taking into account diverse types of family involvement in ownership, resonate with extant research that has started to tackle the issue of having multiple and changing reference points (e.g., Kotlar et al., 2014), and a broader and more specific use of BAM in the family business context (e.g., Lim et al., 2010).

We contribute to family business literature in two main ways. First, we consider different nuances of family influence in management and ownership as determinants of growth, an important yet challenging result for family firms. In so doing, we provide new insights on the need to take into account different types of relationships and distinctions among family members with leading strategic decision-making positions (Chrisman et al., 2018; Daspit et 
al., 2018; Fattoum-Guedri et al., 2018). Indeed, considering the distinction between family and non-family managers, family and non-family owners, active and passive family shareholders, and owners from different generations, we take into account their different motives and show that family members differ in terms of risk-bearing according to their position in the business (Evert et al., 2018), thus affecting whether the firm is more or less oriented towards growth. This helps further the debate on the heterogeneity of family firms (Chua et al., 2012). A second contribution concerns the importance of EO as an attitudinal and behavioral mechanism that renders family involvement in the TMT an effective determinant of family firm growth, thus representing a firm's growth attitude (Covin et al., 2006). In particular, the interplay of ownership and management configurations and EO contributes to developing a model that considers both the demographic and essence dimensions (e.g., Basco, 2013) in predicting growth.

\section{Theoretical and practical implications}

Our work also offers implications for theory and practice. The behavioral agency model provides the lens to discuss the role of framing situations according to specific reference points (Wiseman and Gómez-Mejía, 1998) when diverse configurations of family involvement are considered. Nevertheless, family members appointed in different positions in the business can perceive the situation differently, considering the relationship they have with their peers. We complement previous contributions (e.g., Lim et al., 2010) by expanding the predictive power of BAM in the family business context, and considering the contingency role of different types of owners whose interests might diverge. In so doing, we further elaborate on the general assumption that family influence helps predict how risk-bearing affects strategic decisionmaking, showing that heterogeneity in the ownership structure and in owners' interests influence such relationship. 
Practitioners should carefully consider our model predictions to accurately assess the ownership and management structure in the organization to promote EO and growth. Indeed, our findings show that it is important to not only determine the proportion of family members in the TMT, but also plan succession and assess the proportion of equity in the hands of active $v s$. passive family members.

\section{Limitations and future research directions}

This study is not free from limitations, which provide relevant directions for future research. From a theoretical point of view, family firm growth has been analyzed in a fragmented way, and different dimensions are commonly included under the same umbrella. Although there are some attempts to disentangle the differences between sales growth and employment growth (e.g., Diwisch et al., 2009), future research could more directly theorize what affects these differences. Moreover, it would be relevant in future research to discuss the difference between short- and long-term outcomes, such as growth, and the role of managerial incentives, which we discuss as a core aspect of BAM, thus explaining firm behavior, and EO, to predict firm outcomes according to a time orientation (Sharma et al., 2014; Stenholm et al., 2016; Zellweger and Sieger, 2012). Similarly, it is important to distinguish between objective and perceptionbased growth, for example, accounting for the contingent situation the family business experiences, and whether the business experiences of the enterprising family actually lead to perceiving declining performance and survival risk (Casillas et al., 2019; DeTienne and Chirico, 2013), which might influence the firm's risk-bearing and strategic posture. In a similar vein, it is important to disentangle the effects of different dimensions of family involvement (e.g., Pittino et al., 2018). In this study, while we have considered family involvement in management and ownership, further research is needed to understand what dynamics and mechanisms intervene to build models that better predict family firm growth. For instance, some studies highlight the importance of growth aspirations of family entrepreneurs (Bhalla $e t$ 
al., 2009; Drakopoulou Dodd et al., 2014), nevertheless, more research is needed to understand the effect of growth aspirations on goal setting and EO, and thus, growth. In addition, we had no opportunity to consider whether the family grows more than the firm, or vice versa, it would thus be interesting in future research to take into account that the lifecycle of the family and the business might follow a different pace, thus affecting the relative importance of family needs with respect to business needs (Bañegil Palacios et al., 2013). Following this line of reasoning, it is also important to consider the stage of the family lifecycle that together with the ownership lifecycle and business circle (Gersick et al., 1997) affect the entrepreneurial endeavors of the family business (Brumana et al., 2017; Minola et al., 2016), and in turn, family firm growth. The conservative behavior of family firms and the related effects on EO and growth could be more pronounced at specific stages of the family lifecycle (e.g., when married owners with children see the firm as a legacy for the heirs; Belenzon et al., 2016).

From a methodological point of view, the STEP data offer unique opportunities to test entrepreneurial practice models, providing a theoretical contribution based on a global sample of family firms. Nevertheless, it is a convenience sample, as each affiliate to the STEP project mainly accessed organizations in its network, and only allows cross-sectional analyses, as it was conducted in only one wave. Future research might thus consider testing a similar or an extended model with longitudinal data to focus on the cultural differences of family firms in the sample and on the different perceptions and aspirations of family members involved in the business. Furthermore, we build our argumentation on the risk-bearing construct; future studies could draw on a qualitative or experimental research design to grasp what risk-bearing means for family businesses (Hair and Sarstedt, 2014), and how it affects significant decisions related to growth.

In sum, in this paper we discuss and test the effect of family involvement in the TMT on family business growth. We also consider the mediating role of EO and the moderating role of 
diverse ownership structures. In so doing, we offer a comprehensive view of family influence over the business and its nuanced effects on family firm growth. Moreover, we emphasize the role of EO as an attitudinal and behavioral mechanism that renders family involvement in the TMT an effective determinant of family firm growth. Our evidence contributes to the application of BAM to the family business context, highlighting the role of different types of shareholders and their interests in shaping risk-bearing in family firms.

\section{References}

Anderson, J.C. and Gerbing, D.W. (1988), "Structural equation modeling in practice: A review and recommended two-step approach", Psychological Bulletin, Vol. 103 No. 3, pp. 411423.

Backman, M. and Palmberg, J. (2015), "Contextualizing small family firms: How does the urban-rural context affect firm employment growth?”, Journal of Family Business Strategy, Vol. 6 No. 4, pp. 247-258.

Bagozzi, R.P. and Yi, Y. (1988), "On the evaluation of structural equation models", Journal of the Academy of Marketing Science, Vol. 16 No. 1, pp. 74-94.

Bañegil Palacios, T.M., Barroso Martínez, A. and Luis Tato Jiménez, J. (2013), "Family growth versus family firm growth: Professional management and succession process", Management Research: Journal of the Iberoamerican Academy of Management, Vol. 11 No. 1, pp. 58-76.

Barbera, F. and Hasso, T. (2013), "Do we need to use an accountant? The sales growth and survival benefits to family SMEs", Family Business Review, Vol. 26 No. 3, pp. 271-292.

Basco, R. (2013), "The family's effect on family firm performance: A model testing the demographic and essence approaches", Journal of Family Business Strategy, Vol. 4 No. 1, pp. 42-66.

Basco, R. and Calabrò, A. (2017), "Who should sit there? Effects of family-oriented objectives on board composition", International Journal of Entrepreneurial Venturing, Vol. 9 No. 1, pp. 81-99.

Basco, R., Calabrò, A. and Campopiano, G. (2018), "Transgenerational entrepreneurship around the world: Implications for family business research and practice", Journal of Family Business Strategy, https://doi.org/10.1016/j.jfbs.2018.03.004.

Belenzon, S., Patacconi, A. and Zarutskie, R. (2016), "Married to the firm? A large-scale investigation of the social context of ownership", Strategic Management Journal, Vol. 37 No. 13, pp. 2611-2638.

Ben-Amar, W. and André, P. (2006), "Separation of ownership from control and acquiring firm performance: The case of family ownership in Canada", Journal of Business Finance \& Accounting, Vol. 33 No. 3-4, pp. 517-543.

Berrone, P., Cruz, C. and Gómez-Mejía, L.R. (2012), "Socioemotional wealth in family firms theoretical dimensions, assessment approaches, and agenda for future research", Family Business Review, Vol. 25 No. 3, pp. 258-279.

Bhalla, A., Lampel, J., Henderson, S. and Watkins, D. (2009), "Exploring alternative strategic management paradigms in high-growth ethnic and non-ethnic family firms", Small Business Economics, Vol. 32 No. 1, pp. 77-94. 
Brumana, M., Minola, T., Garrett, R.P., and Digan, S.P. (2017), "How do family firms launch new businesses? A developmental perspective on internal corporate venturing in family business", Journal of Small Business Management, Vol. 55 No. 4, pp. 594-613.

Burkart, M., Panunzi, F. and Shleifer, A. (2003), "Family firms", Journal of Finance, Vol. 58 No. 5, pp. 2167-2201.

Cabrera-Suárez, K., De Saá-Pérez, P. and García-Almeida, D. (2001), "The succession process from a resource-and knowledge-based view of the family firm", Family Business Review, Vol. 14 No. 1, pp. 37-48.

Carney, M. (2005), "Corporate governance and competitive advantage in family-controlled firms", Entrepreneurship Theory and Practice, Vol. 29 No. 3, pp. 249-265.

Casillas, J.C., Moreno-Menéndez, A.M., Barbero, J.L. and Clinton, E. (2019), "Retrenchment strategies and family involvement: The role of survival risk", Family Business Review, Vol. 32 No. 1, pp. 58-75.

Casillas, J.C. and Moreno, A.M. (2010), "The relationship between entrepreneurial orientation and growth: The moderating role of family involvement", Entrepreneurship and Regional Development, Vol. 22 No. 3-4, pp. 265-291.

Casillas, J.C., Moreno, A.M. and Barbero, J.L. (2010), "A configurational approach of the relationship between entrepreneurial orientation and growth of family firms", Family Business Review, Vol. 23 No. 1, pp. 27-44.

Chandler, G.N. (2015), "Control structures used in family business to manage wealth: operationalization of antecedent and outcome variables", Entrepreneurship Theory and Practice, Vol. 39 No. 6, pp. 1305-1312.

Chen, Q., Hou, W., Li, W., Wilson, C. and Wu, Z. (2014), "Family control, regulatory environment, and the growth of entrepreneurial firms: International evidence", Corporate Governance: An International Review, Vol. 22 No. 2, pp. 132-144.

Chrisman, J.J., Chua, J.H., De Massis, A., Minola, T. and Vismara, S. (2016), "Management processes and strategy execution in family firms: from "what" to "how", Small Business Economics, Vol. 47 No. 3, pp. 719-734.

Chrisman, J.J., Chua, J.H., Le Breton-Miller, I., Miller, D. and Steier, L.P. (2018), "Governance mechanisms and family firms", Entrepreneurship Theory and Practice, Vol. 42 No. 2, pp. 171-186.

Chrisman, J.J., Chua, J.H., Pearson, A.W. and Barnett, T. (2012), "Family involvement, family influence, and family-centered non-economic goals in small firms", Entrepreneurship Theory and Practice, Vol. 36 No. 2, pp. 267-293.

Chrisman, J.J., Chua, J.H. and Sharma, P. (2005), "Trends and directions in the development of a strategic management theory of the family firm", Entrepreneurship Theory and Practice, Vol. 29 No. 5, pp. 555-575.

Chua, J.H., Chrisman, J.J., Kellermanns, F. and Wu, Z. (2011), "Family involvement and new venture debt financing", Journal of Business Venturing, Vol. 26 No. 4, pp. 472-488.

Chua, J.H., Chrisman, J.J., Steier, L.P. and Rau, S.B. (2012), "Sources of heterogeneity in family firms: An introduction", Entrepreneurship Theory and Practice, Vol. 36 No. 6, pp. 1103-1113.

Coad, A. and Timmermans, B. (2014), “Two's company: Composition, structure and performance of entrepreneurial pairs", European Management Review, Vol. 11 No. 2, pp. 117-138.

Covin, J.G., Green, K.M. and Slevin, D.P. (2006), "Strategic process effects on the entrepreneurial orientation-sales growth rate relationship", Entrepreneurship Theory and Practice, Vol. 30 No. 1, pp. 57-81.

Croce, A. and Martí, J. (2016), "Productivity growth in private-equity-backed family firms", Entrepreneurship Theory and Practice, Vol. 40 No. 3, pp. 657-683. 
Cruz, C.C., Gómez-Mejia, L.R. and Becerra, M. (2010), "Perceptions of benevolence and the design of agency contracts: CEO-TMT relationships in family firms", Academy of Management Journal, Vol. 53 No. 1, pp. 69-89.

Daspit, J.J., Chrisman, J.J., Sharma, P., Pearson, A.W. and Mahto, R.V. (2018), "Governance as a source of family firm heterogeneity”, Journal of Business Research, Vol. 84 pp. 293300 .

Davis, P.S. and Harveston, P.D. (1999), "In the founder's shadow: Conflict in the family firm", Family Business Review, Vol. 12 No. 4, pp. 311-323.

De Massis, A., Kotlar, J., Campopiano, G. and Cassia, L. (2013), "Dispersion of family ownership and the performance of small-to-medium size private family firms", Journal of Family Business Strategy, Vol. 4 No. 3, pp. 166-175.

De Massis, A., Kotlar, J., Mazzola, P., Minola, T., and Sciascia, S. (2008), "Conflicting selves: Family owners' multiple goals and self-control agency problems in private firms", Entrepreneurship Theory and Practice, Vol. 42 No. 3, pp. 362-389.

DeTienne, D.R. and Chirico, F. (2013), "Exit Strategies in Family Firms: How Socioemotional Wealth Drives the Threshold of Performance", Entrepreneurship Theory and Practice, pp. 1297-1318.

Diwisch, D., Voithofer, P. and Weiss, C. (2009), "Succession and firm growth: Results from a non-parametric matching approach", Small Business Economics, Vol. 32 No. 1, pp. 45-56.

Drakopoulou Dodd, S., Theoharakis, V. and Bisignano, A. (2014), "Organizational renewal in family firms", The International Journal of Entrepreneurship and Innovation, Vol. 15 No. 2, pp. 67-78.

Eddleston, K.A. and Kellermanns, F.W. (2007), "Destructive and productive family relationships: A stewardship theory perspective", Journal of Business Venturing, Vol. 22 No. 4, pp. 545-565.

Eddleston, K.A., Kellermanns, F.W., Floyd, S.W., Crittenden, V.L. and Crittenden, W.F. (2013), "Planning for growth: Life stage differences in family firms", Entrepreneurship Theory and Practice, Vol. 37 No. 5, pp. 1177-1202.

Eddleston, K.A., Otondo, R.F. and Kellermanns, F.W. (2008), "Conflict, participative decision-making, and generational ownership dispersion: A multilevel analysis", Journal of Small Business Management, Vol. 46 No. 3, pp. 456-484.

Evert, R.E., Sears, J.B., Martin, J.A. and Payne, G.T. (2018), "Family ownership and family involvement as antecedents of strategic action: A longitudinal study of initial international entry", Journal of Business Research, Vol. 84, pp. 301-311.

Fattoum-Guedri, A., Guedri, Z. and Delmar, F. (2018), "Multiple blockholder structures and family firm performance", Entrepreneurship Theory and Practice, Vol. 42 No. 2, pp. 231251.

Ford, J.K., MacCallum, R.C. and Tait, M. (1986), "The application of exploratory factor analysis in applied psychology: A critical review and analysis", Personnel Psychology, Vol. 39 No. 2, pp. 291-314.

Fornell, C. and Larcker, D.F. (1981), "Evaluating structural equation models with unobservable variables and measurement error", Journal of Marketing Research, Vol. 18 No. 1, pp. 39-50.

Foss, N.J., Lyngsie, J. and Zahra, S.A. (2013), "The role of external knowledge sources and organizational design in the process of opportunity exploitation", Strategic Management Journal, Vol. 34 No. 12, pp. 1453-1471.

Garcia-Castro, R. and Aguilera, R.V. (2014), "Family involvement in business and financial performance: A set-theoretic cross-national inquiry", Journal of Family Business Strategy, Vol. 5 No. 1, pp. 85-96. 
Gersick, K.E., Davis, J.A., McCollom Hampton, M. and Lansberg, I. (1997), Generation to generation: Life cycles of the family business. Harvard Business Press, Boston, MA.

Gómez-Mejía, L.R., Cruz, C., Berrone, P. and De Castro, J. (2011), "The bind that ties: Socioemotional wealth preservation in family firms", Academy of Management Annals, Vol. 5 No. 1, pp. 653-707.

Gómez-Mejía, L.R., Haynes, K.T., Núñez-Nickel, M., Jacobson, K.J. and Moyano-Fuentes, J. (2007), "Socioemotional wealth and business risks in family-controlled firms: Evidence from Spanish olive oil mills", Administrative Science Quarterly, Vol. 52 No. 1, pp. 106137.

Gómez-Mejía, L.R., Larraza-Kintana, M. and Makri, M. (2003), "The determinants of executive compensation in family-controlled public corporations", Academy of Management Journal, Vol. 46 No. 2, pp. 226-237.

Gómez-Mejía, L.R., Makri, M. and Kintana, M.L. (2010), "Diversification decisions in familycontrolled firms", Journal of Management Studies, Vol. 47 No. 2, pp. 223-252.

González, M., Guzmán, A., Pombo, C. and Trujillo, M.-A. (2014), "Family involvement and dividend policy in closely held firms", Family Business Review, Vol. 27 No. 4, pp. 365-385.

Guidice, R.M., Mero, N.P. and Greene, J.V. (2013), "Perceptions of accountability in family business: Using accountability theory to understand differences between family and nonfamily executives", Journal of Family Business Strategy, Vol. 4 No. 4, pp. 233-244.

Habbershon, T.G., Nordqvist, M. and Zellweger, T. (2010), "Transgenerational entrepreneurship". In Nordqvist, M. and Zellweger, T. (Eds.) Transgenerational entrepreneurship: Exploring growth and performance in family firms across generations. Edward Elgar, Cheltenham, UK, pp 1-38.

Hair, J.F., Hult, G.T.M., Ringle, C. and Sarstedt, M. (2016), A primer on partial least squares structural equation modeling (PLS-SEM). Sage Publications, London, UK.

Hair, J.F. and Sarstedt, M. (2014), "Innovative and established research methods in family business: description, illustration and application guidelines", Journal of Family Business Strategy, Vol. 5 No. 1, pp. 1-3.

Hair, J.F., Sarstedt, M., Pieper, T.M. and Ringle, C.M. (2012), "The use of partial least squares structural equation modeling in strategic management research: A review of past practices and recommendations for future applications", Long Range Planning, Vol. 45 No. 5, pp. 320-340.

Hall, A., Melin, L. and Nordqvist, M. (2001), "Entrepreneurship as radical change in the family business: Exploring the role of cultural patterns", Family Business Review, Vol. 14 No. 3, pp. 193-208.

Hamelin, A. (2013), "Influence of family ownership on small business growth. Evidence from French SMEs", Small Business Economics, Vol. 41 No. 3, pp. 563-579.

Hayes, A.F. (2009), "Beyond Baron and Kenny: Statistical mediation analysis in the new millennium”, Communication Monographs, Vol. 76 No. 4, pp. 408-420.

Hayes, A.F. (2015), "An index and test of linear moderated mediation", Multivariate Behavioral Research, Vol. 50 No. 1, pp. 1-22.

Henseler, J., Ringle, C.M. and Sarstedt, M. (2015), "A new criterion for assessing discriminant validity in variance-based structural equation modeling", Journal of the Academy of Marketing Science, Vol. 43 No. 1, pp. 115-135.

Holt, D.T., Madison, K. and Kellermanns, F.W. (2017), "Variance in family members' assessments: The importance of dispersion modeling in family firm research", Family Business Review, Vol. 30 No. 1, pp. 61-83.

Hoskisson, R.E., Chirico, F., Zyung, J. and Gambeta, E. (2017), "Managerial risk taking: A multitheoretical review and future research agenda", Journal of Management, Vol. 43 No. 1, pp. 137-169. 
Hult, G.T.M., Hair Jr, F., Proksch, D., Sarstedt, M., Pinkwart, A. and Ringle, C.M. (2018), "Addressing endogeneity in international marketing applications of partial least squares structural equation modeling", Journal of International Marketing, Vol. 26 No. 3, pp. 1-21.

Iacobucci, D., Saldanha, N. and Deng, X. (2007), "A meditation on mediation: Evidence that structural equations models perform better than regressions", Journal of Consumer Psychology, Vol. 17 No. 2, pp. 139-153.

Ingram, A.E., Lewis, M.W., Barton, S. and Gartner, W.B. (2016), "Paradoxes and innovation in family firms: The role of paradoxical thinking", Entrepreneurship Theory and Practice, Vol. 40 No. 1, pp. 161-176.

Kellermanns, F.W., Eddleston, K.A., Sarathy, R. and Murphy, F. (2012), "Innovativeness in family firms: A family influence perspective", Small Business Economics, Vol. 38 No. 1, pp. 85-101.

Kelly, L.M., Athanassiou, N. and Crittenden, W.F. (2000), "Founder centrality and strategic behavior in the family-owned firm", Entrepreneurship Theory and Practice, Vol. 25 No. 2 , pp. $27-42$.

Klein, K.J. and Kozlowski, S.W. (2000), "From micro to meso: Critical steps in conceptualizing and conducting multilevel research", Organizational Research Methods, Vol. 3 No. 3, pp. 211-236.

Klein, P., Shapiro, D. and Young, J. (2005), "Corporate governance, family ownership and firm value: The Canadian evidence", Corporate Governance: An International Review, Vol. 13 No. 6, pp. 769-784.

Kotlar, J., De Massis, A., Fang, H. and Frattini, F. (2014), "Strategic reference points in family firms", Small Business Economics, Vol. 43 No. 3, pp. 597-619.

Le Breton-Miller, I. and Miller, D. (2008), "To grow or to harvest? Governance, strategy and performance in family and lone founder firms", Journal of Strategy and Management, Vol. 1 No. 1, pp. 41-56.

Le Breton-Miller, I. and Miller, D. (2013), "Socioemotional wealth across the family firm life cycle: A commentary on "Family Business Survival and the Role of Boards"", Entrepreneurship Theory and Practice, Vol. 37 No. 6, pp. 1391-1397.

Lee, J. (2006), "Family firm performance: Further evidence", Family Business Review, Vol. 19 No. 2, pp. 103-114.

Lim, E.N., Lubatkin, M.H. and Wiseman, R.M. (2010), "A family firm variant of the behavioral agency theory", Strategic Entrepreneurship Journal, Vol. 4 No. 3, pp. 197-211.

Ling, Y. and Kellermanns, F.W. (2010), "The effects of family firm specific sources of TMT diversity: The moderating role of information exchange frequency", Journal of Management Studies, Vol. 47 No. 2, pp. 322-344.

Lumpkin, G.T. and Dess, G.G. (1996), "Clarifying the entrepreneurial orientation construct and linking it to performance", Academy of Management Review, Vol. 21 No. 1, pp. 135172.

Lumpkin, G.T. and Dess, G.G. (2001), "Linking two dimensions of entrepreneurial orientation to firm performance: The moderating role of environment and industry life cycle", Journal of Business Venturing, Vol. 16 No. 5, pp. 429-451.

McKelvie, A., McKenny, A., Lumpkin, G. and Short, J.C. (2014), "Corporate entrepreneurship in family businesses: Past contributions and future opportunities". In Melin, L., Nordqvist, M. and Sharma, P. (Eds.) SAGE handbook of family business. SAGE Publications, London, UK, pp 340-363.

Michiels, A., Voordeckers, W., Lybaert, N. and Steijvers, T. (2015), "Dividends and family governance practices in private family firms", Small Business Economics, Vol. 44 No. 2, pp. 299-314. 
Miller, D. and Le Breton-Miller, I. (2006), "Family governance and firm performance: Agency, stewardship, and capabilities", Family Business Review, Vol. 19 No. 1, pp. 73-87.

Miller, D., Le Breton-Miller, I. and Lester, R.H. (2011), "Family and lone founder ownership and strategic behaviour: Social context, identity, and institutional logics", Journal of Management Studies, Vol. 48 No. 1, pp. 1-25.

Minola, T., Brumana, M., Campopiano, G., Garrett, R.P. and Cassia, L. (2016), "Corporate venturing in family business: A developmental approach of the enterprising family", Strategic Entrepreneurship Journal, Vol. 10 No. 4, pp. 395-412.

Molly, V., Laveren, E. and Jorissen, A. (2012), "Intergenerational differences in family firms: Impact on capital structure and growth behavior", Entrepreneurship Theory and Practice, Vol. 36 No. 4, pp. 703-725.

Moreno, A.M. and Casillas, J.C. (2008), "Entrepreneurial orientation and growth of SMEs: A Causal model", Entrepreneurship Theory and Practice, Vol. 32 No. 3, pp. 507-528.

Naldi, L., Cennamo, C., Corbetta, G. and Gómez-Mejía, L. (2013), "Preserving socioemotional wealth in family firms: Asset or liability? The moderating role of business context", Entrepreneurship Theory and Practice, Vol. 37 No. 6, pp. 1341-1360.

Naldi, L., Nordqvist, M., Sjöberg, K. and Wiklund, J. (2007), "Entrepreneurial orientation, risk taking, and performance in family firms", Family Business Review, Vol. 20 No. 1, pp. 3347.

O’Boyle, E.H., Pollack, J.M. and Rutherford, M.W. (2012), "Exploring the relation between family involvement and firms' financial performance: A meta-analysis of main and moderator effects", Journal of Business Venturing, Vol. 27 No. 1, pp. 1-18.

Pittino, D., Martínez, A.B., Chirico, F. and Galván, R.S. (2018), "Psychological ownership, knowledge sharing and entrepreneurial orientation in family firms: The moderating role of governance heterogeneity", Journal of Business Research, Vol. 84 pp. 312-326.

Pittino, D., Visintin, F. and Lauto, G. (2017), "A configurational analysis of the antecedents of entrepreneurial orientation", European Management Journal, Vol. 35 No. 2, pp. 224-237.

Preacher, K.J., Rucker, D.D. and Hayes, A.F. (2007), "Addressing moderated mediation hypotheses: Theory, methods, and prescriptions", Multivariate Behavioral Research, Vol. 42 No. 1, pp. 185-227.

Rauch, A., Wiklund, J., Lumpkin, G.T. and Frese, M. (2009), "Entrepreneurial orientation and business performance: An assessment of past research and suggestions for the future", Entrepreneurship Theory and Practice, Vol. 33 No. 3, pp. 761-787.

Salvato, C., Chirico, F. and Sharma, P. (2010), "A farewell to the business: Championing exit and continuity in entrepreneurial family firms", Entrepreneurship and Regional Development, Vol. 22 No. 3-4, pp. 321-348.

Sanchez-Bueno, M.J. and Usero, B. (2014), "How may the nature of family firms explain the decisions concerning international diversification?", Journal of Business Research, Vol. 67 No. 7, pp. 1311-1320.

Sarstedt, M., Ringle, C.M., Smith, D., Reams, R. and Hair, J.F. (2014), "Partial least squares structural equation modeling (PLS-SEM): A useful tool for family business researchers", Journal of Family Business Strategy, Vol. 5 No. 1, pp. 105-115.

Schulze, W.S., Lubatkin, M.H. and Dino, R.N. (2003), "Exploring the agency consequences of ownership dispersion among the directors of private family firms", Academy of Management Journal, Vol. 46 No. 2, pp. 179-194.

Sciascia, S. and Mazzola, P. (2008), "Family involvement in ownership and management: Exploring nonlinear effects on performance", Family Business Review, Vol. 21 No. 4, pp. 331-345. 
Sciascia, S., Mazzola, P. and Kellermanns, F.W. (2014), "Family management and profitability in private family-owned firms: Introducing generational stage and the socioemotional wealth perspective", Journal of Family Business Strategy, Vol. 5 No. 2, pp. 131-137.

Sharma, P., Salvato, C. and Reay, T. (2014), "Temporal dimensions of family enterprise research", Family Business Review, Vol. 27 No. 1, pp. 10-19.

Sirmon, D.G. and Hitt, M.A. (2003), "Managing resources: Linking unique resources, management, and wealth creation in family firms", Entrepreneurship Theory and Practice, Vol. 27 No. 4, pp. 339-358.

Smilkstein, G., Ashworth, C. and Montano, D. (1982), "Validity and reliability of the family APGAR as a test of family function", The Journal of Family Practice, Vol. 5 No. 2, pp. 303-311.

Steier, L. (2003), "Variants of agency contracts in family-financed ventures as a continuum of familial altruistic and market rationalities", Journal of Business Venturing, Vol. 18 No. 5, pp. 597-618.

Steiger, J.H. (1990), "Structural model evaluation and modification: An interval estimation approach”, Multivariate Behavioral Research, Vol. 25 No. 2, pp. 173-180.

Stenholm, P., Pukkinen, T. and Heinonen, J. (2016), "Firm Growth in Family BusinessesThe Role of Entrepreneurial Orientation and the Entrepreneurial Activity", Journal of Small Business Management, Vol. 54 No. 2, pp. 697-713.

STEP (2015) 'Family-Owned Businesses are Determined to Maintain Ownership and Control of Their Companies', [online], available: http://www.babson.edu/news-events/babsonnews/Pages/2015-latest-successful-transgenerational-entrepreneurship-practices-stepproject-survey-results.aspx [accessed 20 January 2018].

Upton, N. and Petty, W. (2000), "Venture capital investment and US family business", Venture Capital: An International Journal of Entrepreneurial Finance, Vol. 2 No. 1, pp. 27-39.

Upton, N., Teal, E.J. and Felan, J.T. (2001), "Strategic and business planning practices of fast growth family firms", Journal of Small Business Management, Vol. 39 No. 1, pp. 60-72.

Westhead, P. and Howorth, C. (2006), "Ownership and management issues associated with family firm performance and company objectives", Family Business Review, Vol. 19 No. 4, pp. 301-316.

Williams, L.J., Hartman, N. and Cavazotte, F. (2010), "Method variance and marker variables: A review and comprehensive CFA marker technique", Organizational Research Methods, Vol. 13 No. 3, pp. 477-514.

Wiseman, R.M. and Gómez-Mejía, L.R. (1998), “A behavioral agency model of managerial risk taking", Academy of Management Review, Vol. 23 No. 1, pp. 133-153.

Young, M.N., Peng, M.W., Ahlstrom, D., Bruton, G.D. and Jiang, Y. (2008), "Corporate governance in emerging economies: A review of the principal-principal perspective", Journal of Management Studies, Vol. 45 No. 1, pp. 196-220.

Zellweger, T. and Sieger, P. (2012), "Entrepreneurial orientation in long-lived family firms", Small Business Economics, Vol. 38 No. 1, pp. 67-84.

Zellweger, T.M., Nason, R.S. and Nordqvist, M. (2011), "From longevity of firms to transgenerational entrepreneurship of families: Introducing family entrepreneurial orientation", Family Business Review, Vol. 25 No. 2, pp. 136-155. 
Table 1 Validation of the final measurement model

\begin{tabular}{|c|c|c|c|}
\hline Construct & Indicator & $\begin{array}{l}\text { Standardized } \\
\text { loading }\end{array}$ & T-value \\
\hline Growth & G_1 & $0.902 * * *$ & 62.53 \\
\hline CR: 0.844 & $\mathrm{G} \_2$ & $0.883 * * *$ & 58.57 \\
\hline \multirow[t]{2}{*}{ AVE: 0.583} & G_3 & $0.604 * * *$ & 21.10 \\
\hline & G_4 & $0.612 * * *$ & 21.69 \\
\hline Entrepreneurial & EO_1 & $0.421 * * *$ & 10.91 \\
\hline orientation & EO_2 & $0.476 * * *$ & 13.02 \\
\hline CR: 0.837 & EO_3 & $0.602 * * *$ & 19.17 \\
\hline \multirow[t]{7}{*}{ AVE: 0.349} & EO_4 & $0.672 * * *$ & 24.44 \\
\hline & EO_5 & $0.617 * * *$ & 20.55 \\
\hline & EO_6 & $0.813 * * *$ & 39.17 \\
\hline & EO_7 & $0.649 * * *$ & 22.56 \\
\hline & EO_8 & $0.643 * * *$ & 22.15 \\
\hline & EO_9 & $0.467 * * *$ & 12.77 \\
\hline & EO_10 & $0.420 * * *$ & 10.92 \\
\hline
\end{tabular}

$\chi^{2}(279$ d.f. $)=444.19 ; \mathrm{CFI}=0.952 ; \mathrm{TLI}=0.943 ; \mathrm{RMSEA}=0.034 ; \mathrm{R}^{2}=0.22$.

$* * * \mathrm{p}<0.001 ; \mathrm{CR}=$ composite reliability; $\mathrm{AVE}=$ average variance extracted.

Table 2 Squared construct correlations and average variance extracted

\begin{tabular}{|c|c|c|c|c|c|c|}
\hline & 1. & 2. & 3. & 4. & 5. & 6. \\
\hline $\begin{array}{l}\text { 1. Family Involvement in the } \\
\text { TMT }\end{array}$ & $0^{\mathbf{a}}$ & & & & & \\
\hline $\begin{array}{l}\text { 2. Presence of Non-Family } \\
\text { Shareholders }\end{array}$ & 0.025 & $0^{a}$ & & & & \\
\hline $\begin{array}{l}\text { 3. Passive Family Members } \\
\text { as Major Shareholders }\end{array}$ & 0.047 & 0.002 & $0^{a}$ & & & \\
\hline $\begin{array}{l}\text { 4. Multigenerational } \\
\text { Involvement in Ownership }\end{array}$ & 0.011 & 0.001 & 0.021 & $0^{a}$ & & \\
\hline $\begin{array}{l}\text { 5. Entrepreneurial } \\
\text { Orientation }\end{array}$ & 0.024 & 0.007 & 0.001 & 0.002 & 0.345 & \\
\hline 6. Growth & 0.000 & 0.000 & 0.001 & 0.000 & 0.095 & 0.596 \\
\hline
\end{tabular}

Numbers in bold indicate the AVE. No squared correlation (off-diagonal) is greater than the corresponding AVE.

${ }^{a}$ Single indicator construct. 
Table 3 Mean, standard deviations, and correlations

\begin{tabular}{|c|c|c|c|c|c|c|c|c|c|c|c|c|c|c|c|}
\hline & Mean & s.d. & 1. & 2. & 3. & 4. & 5. & 6. & 7. & 8. & 9. & 10. & 11. & 12. & 13. \\
\hline 1. FI TMT & 0.58 & 0.35 & & & & & & & & & & & & & \\
\hline 2. PNFS & 0.25 & 0.44 & $0.6698^{*}$ & & & & & & & & & & & & \\
\hline 3. PFMS & 0.16 & 0.37 & $0.3204 *$ & $0.4068 *$ & & & & & & & & & & & \\
\hline 4. MIO & 0.47 & 0.50 & $0.2895^{*}$ & $0.3310 *$ & $0.5685^{*}$ & & & & & & & & & & \\
\hline 5. EO_1 & 2.79 & 0.99 & $0.3169^{*}$ & $0.3639^{*}$ & $0.3588^{*}$ & $0.4438^{*}$ & & & & & & & & & \\
\hline 6. EO_2 & 2.79 & 0.96 & $0.2740 *$ & $0.3145^{*}$ & $0.4810^{*}$ & $0.5696^{*}$ & $0.4870 *$ & & & & & & & & \\
\hline 7. EO_3 & 3.53 & 1.00 & $0.2065^{*}$ & $0.2715^{*}$ & $0.3356^{*}$ & $0.4080^{*}$ & $0.3844 *$ & $0.5782^{*}$ & & & & & & & \\
\hline 8. EO_4 & 3.75 & 0.99 & $0.2640^{*}$ & $0.2989 *$ & $0.3234 *$ & $0.3695^{*}$ & $0.3985^{*}$ & $0.5570^{*}$ & $0.6934 *$ & & & & & & \\
\hline 9. EO_5 & 3.28 & 1.09 & $0.2672^{*}$ & $0.2567 *$ & $0.3079 *$ & $0.2507 *$ & $0.2287 *$ & $0.3517^{*}$ & $0.3185^{*}$ & $0.3372^{*}$ & & & & & \\
\hline 10. EO_6 & 3.65 & 1.10 & $0.3203^{*}$ & $0.2779^{*}$ & $0.2588^{*}$ & $0.2543^{*}$ & $0.2669^{*}$ & $0.2890^{*}$ & $0.2456^{*}$ & $0.2718^{*}$ & $0.6556^{*}$ & & & & \\
\hline 11. EO_7 & 3.97 & 1.02 & $0.2102 *$ & $0.1573 *$ & $0.2458^{*}$ & $0.2222^{*}$ & $0.1357 *$ & $0.2650^{*}$ & $0.1600^{*}$ & $0.2473^{*}$ & $0.2680 *$ & $0.2438^{*}$ & & & \\
\hline 12. EO_8 & 3.73 & 0.99 & $0.2304^{*}$ & $0.1851 *$ & $0.2645^{*}$ & $0.2183^{*}$ & $0.1926^{*}$ & $0.2697^{*}$ & $0.2024 *$ & $0.3073^{*}$ & $0.2978^{*}$ & $0.2807 *$ & $0.7973^{*}$ & & \\
\hline 13. EO_9 & 3.42 & 0.98 & $0.2118^{*}$ & $0.1823 *$ & $0.1880^{*}$ & $0.1936^{*}$ & $0.1609 *$ & $0.2020^{*}$ & $0.1370 *$ & $0.2388^{*}$ & $0.1766^{*}$ & $0.1496^{*}$ & $0.5490^{*}$ & $0.5378^{*}$ & \\
\hline 14. EO_10 & 3.11 & 0.95 & $0.1333^{*}$ & $0.0821 *$ & $0.2175^{*}$ & $0.1531^{*}$ & 0.0568 & $0.1854^{*}$ & $0.1311 *$ & $0.2059^{*}$ & $0.2020 *$ & $0.1478^{*}$ & $0.5625^{*}$ & $0.5370 *$ & $0.3089^{*}$ \\
\hline 15. G_1 & 3.77 & 0.85 & -0.0758 & $-0.0846^{*}$ & $-0.1151 *$ & -0.0554 & $-0.0973 *$ & $-0.1473 *$ & $-0.1246^{*}$ & -0.0528 & $-0.1589 *$ & $-0.1790 *$ & $-0.1189^{*}$ & $-0.1063 *$ & $-0.1119 *$ \\
\hline 16. G_2 & 3.71 & 0.81 & -0.0159 & -0.0211 & -0.0164 & -0.0737 & -0.0108 & -0.0579 & -0.0184 & -0.0486 & 0.0037 & -0.0062 & -0.0104 & 0.0037 & -0.0158 \\
\hline 17. G_3 & 3.45 & 0.81 & -0.0473 & 0.0185 & -0.024 & -0.0088 & -0.0231 & -0.0379 & 0.0521 & 0.0007 & -0.0279 & -0.001 & 0.0111 & 0.0015 & -0.0607 \\
\hline 18. G_4 & 3.61 & 0.86 & 0.0526 & 0.0572 & 0.0778 & 0.0432 & 0.0567 & 0.0527 & 0.0224 & -0.0275 & -0.0031 & -0.004 & 0.0324 & 0.0178 & -0.0516 \\
\hline 19. Firm age & 52.41 & 41.14 & -0.0497 & 0.0022 & $0.0857^{*}$ & 0.0415 & 0.0526 & 0.0653 & 0.0721 & -0.0072 & 0.0247 & 0.0595 & -0.0447 & 0.0064 & 0.0014 \\
\hline 20. Firm size & 764.67 & 3396.13 & 0.0536 & 0.0701 & 0.063 & 0.0141 & -0.0022 & 0.0257 & 0.0399 & -0.0092 & 0.0662 & $0.1145^{*}$ & 0.0478 & 0.0577 & $0.1275^{*}$ \\
\hline 22. North America & 0.28 & 0.45 & $0.0974 *$ & 0.0504 & -0.0212 & -0.0149 & $-0.0894 *$ & -0.0511 & $-0.0855^{*}$ & -0.0068 & $0.1753^{*}$ & $0.1431 *$ & 0.028 & 0.0329 & -0.0549 \\
\hline 23. Latin America & 0.16 & 0.36 & 0.0382 & -0.0175 & -0.005 & 0.0123 & -0.0597 & -0.0059 & -0.0006 & 0.0337 & -0.0564 & -0.0634 & 0.0535 & 0.0065 & 0.0101 \\
\hline 24. Europe & 0.49 & 0.50 & -0.0649 & 0.039 & $0.0956^{*}$ & 0.0613 & $0.1159^{*}$ & $0.1120^{*}$ & $0.1169 *$ & 0.0274 & -0.0669 & -0.0453 & 0.0144 & 0.0223 & 0.0585 \\
\hline 25. Manufacturing & 0.53 & 0.50 & 0.0187 & 0.0166 & 0.0434 & -0.0079 & 0.0392 & 0.0346 & 0.0281 & -0.018 & 0.0529 & $0.0947 *$ & 0.0107 & 0.0048 & 0.0035 \\
\hline $\begin{array}{l}\text { 26. Profits to } \\
\text { reinvest }\end{array}$ & 3.80 & 1.04 & $0.1127^{*}$ & $0.0994 *$ & $0.1083^{*}$ & $0.1774 *$ & $0.1256^{*}$ & $0.1553^{*}$ & $0.1556^{*}$ & $0.1382^{*}$ & $0.1209^{*}$ & $0.1622 *$ & $0.2372^{*}$ & $0.2632 *$ & $0.1883^{*}$ \\
\hline $\begin{array}{l}\text { 27. Relationships } \\
\text { within }\end{array}$ & 4.28 & 0.69 & $0.1281^{*}$ & $0.0910^{*}$ & $0.1512^{*}$ & $0.1528^{*}$ & $0.0852^{*}$ & $0.1708^{*}$ & $0.1006^{*}$ & $0.1487^{*}$ & $0.1727^{*}$ & $0.1549^{*}$ & $0.2305^{*}$ & $0.1940^{*}$ & $0.1530^{*}$ \\
\hline $\begin{array}{l}\text { 28. Collaborations } \\
\text { with customers }\end{array}$ & 4.31 & 0.72 & 0.0468 & -0.0055 & $0.1029 *$ & $0.1158^{*}$ & 0.058 & $0.1238^{*}$ & $0.0952 *$ & $0.1447^{*}$ & $0.1501 *$ & $0.1121^{*}$ & $0.1819 *$ & 0.1997* & $0.1652 *$ \\
\hline
\end{tabular}


Table 3 (Continued)

\begin{tabular}{|c|c|c|c|c|c|c|c|c|c|c|c|c|c|}
\hline & 14. & 15. & 16. & 17. & 18. & 19. & 20. & 21. & 22. & 23. & 24. & 25. & 26. \\
\hline 15. G_1 & -0.0638 & & & & & & & & & & & & \\
\hline 16. G_2 & 0.0183 & $-0.1581^{*}$ & & & & & & & & & & & \\
\hline 17. G_3 & -0.0208 & $-0.2159 *$ & -0.0331 & & & & & & & & & & \\
\hline 18. G_4 & -0.024 & $-0.1040^{*}$ & -0.024 & $0.1421^{*}$ & & & & & & & & & \\
\hline 19. Firm age & -0.0256 & $-0.2053 *$ & -0.033 & $0.2060^{*}$ & $0.1143 *$ & & & & & & & & \\
\hline 20. Firm size & 0.0359 & $-0.1726^{*}$ & 0.0114 & 0.0072 & -0.0181 & $0.0962 *$ & & & & & & & \\
\hline 22. North America & 0.0736 & $0.0989^{*}$ & -0.0448 & -0.023 & -0.0089 & $-0.0965^{*}$ & -0.0693 & & & & & & \\
\hline 23. Latin America & 0.0364 & -0.0022 & -0.0335 & 0.0035 & 0.002 & $-0.1645^{*}$ & -0.0138 & $-0.2644 *$ & & & & & \\
\hline 24. Europe & -0.024 & $-0.1464 *$ & 0.0443 & 0.0729 & $0.1092 *$ & $0.2694 *$ & 0.077 & $-0.5998 *$ & $-0.4161 *$ & & & & \\
\hline 25. Manufacturing & 0.0366 & -0.02 & 0.018 & 0.0388 & -0.0181 & $0.1313^{*}$ & $0.0923 *$ & $-0.0814 *$ & 0.0313 & 0.0037 & & & \\
\hline $\begin{array}{l}26 . \text { Profits to } \\
\text { reinvest }\end{array}$ & $0.2402^{*}$ & $-0.1873 *$ & -0.0077 & -0.0447 & -0.0019 & 0.067 & $0.0932 *$ & -0.0398 & -0.0447 & $0.0858^{*}$ & 0.0203 & & \\
\hline $\begin{array}{l}\text { 27. Relationships } \\
\text { within }\end{array}$ & $0.1729 *$ & 0.0054 & 0.0524 & $-0.0857^{*}$ & -0.002 & -0.0289 & 0.0165 & $0.1608^{*}$ & 0.0396 & $-0.0932 *$ & -0.0491 & $0.1997 *$ & \\
\hline $\begin{array}{l}\text { 28. Collaborations } \\
\text { with customers }\end{array}$ & $0.1898 *$ & 0.0035 & -0.0477 & -0.0705 & $-0.1076 *$ & 0.0269 & -0.057 & $0.0955^{*}$ & 0.0469 & $-0.0994 *$ & -0.0195 & $0.1728^{*}$ & $0.4649 *$ \\
\hline
\end{tabular}

PNFS = Presence of Non-Family Shareholders, PFMS = Passive Family Members as Major Shareholders, MIO = Multigenerational Involvement in Ownership. 
Table 4 Path coefficients and t-values of the model without moderated mediation

\begin{tabular}{lcc}
\hline Path (without moderated mediation) & $\boldsymbol{\beta}$ & t-value \\
\hline Family Involvement in TMT $\rightarrow$ Growth & $-0.187 * *$ & -1.98 \\
Firm age $\rightarrow$ Growth & $-0.001 f$ & -1.77 \\
Firm size $\rightarrow$ Growth & 0.000 & 0.99 \\
North America $\rightarrow$ Growth & $0.299^{*}$ & 2.37 \\
Latin America $\rightarrow$ Growth & $0.323 *$ & 2.38 \\
Europe $\rightarrow$ Growth & $0.305^{*}$ & 2.53 \\
Manufacturing $\rightarrow$ Growth & 0.045 & 0.72 \\
Profits to reinvest $\rightarrow$ Growth & $0.163 * * *$ \\
Relationships within $\rightarrow$ Growth & $0.135^{* *}$ & 5.21 \\
Collaborations with customers $\rightarrow$ Growth & $0.138^{* *}$ & 2.75 \\
$\mathrm{~N}=587 ; \chi^{2}\left(32\right.$ d.f.) $=49.65 ;$ CFI $=0.985 ;$ TLI $=0.978 ;$ RMSEA $=0.031 ; \mathrm{R}^{2}=0.15$. & 2.63
\end{tabular}


Table 5 Path coefficients and t-values of the model with moderated mediation

\begin{tabular}{|c|c|c|}
\hline Path (with moderated mediation) & $\boldsymbol{\beta}$ & t-value \\
\hline Family Involvement in TMT $\rightarrow$ EO & $-0.153 * * *$ & -3.32 \\
\hline $\mathrm{PNFS} \rightarrow \mathrm{EO}$ & $-0.085 \dagger$ & -1.93 \\
\hline PFMS $\rightarrow$ EO & -0.036 & -0.76 \\
\hline $\mathrm{MIO} \rightarrow \mathrm{EO}$ & 0.047 & 1.06 \\
\hline Family Involvement in TMT $*$ PNFS $\rightarrow$ EO & 0.027 & 0.62 \\
\hline Family Involvement in TMT $*$ PFMS $\rightarrow$ EO & $0.081 f$ & 1.77 \\
\hline Family Involvement in $\mathrm{TMT} * \mathrm{MIO} \rightarrow \mathrm{EO}$ & $-0.083^{*}$ & -1.92 \\
\hline Firm age $\rightarrow$ EO & 0.001 & 0.02 \\
\hline Firm size $\rightarrow$ EO & 0.002 & 0.04 \\
\hline North America $\rightarrow$ EO & 0.108 & 1.38 \\
\hline Latin America $\rightarrow$ EO & 0.086 & 1.27 \\
\hline Europe $\rightarrow$ EO & $0.203 *$ & 2.44 \\
\hline Manufacturing $\rightarrow$ EO & 0.047 & 1.08 \\
\hline Profits to reinvest $\rightarrow$ EO & $0.135^{* *}$ & 3.04 \\
\hline Relationships within $\rightarrow$ EO & $0.161 * *$ & 3.25 \\
\hline Collaborations with customers $\rightarrow$ EO & 0.067 & 1.36 \\
\hline EO $\rightarrow$ Growth & $0.319 * * *$ & 7.19 \\
\hline Family Involvement in TMT $\rightarrow$ Growth & -0.036 & -0.84 \\
\hline PNFS $\rightarrow$ Growth & 0.013 & 0.34 \\
\hline PFMS $\rightarrow$ Growth & 0.028 & 0.70 \\
\hline MIO $\rightarrow$ Growth & 0.001 & 0.00 \\
\hline Firm age $\rightarrow$ Growth & $-0.08 f$ & -1.89 \\
\hline Firm size $\rightarrow$ Growth & 0.042 & 1.06 \\
\hline North America $\rightarrow$ Growth & $0.134 f$ & 1.87 \\
\hline Latin America $\rightarrow$ Growth & $0.117 f$ & 1.88 \\
\hline Europe $\rightarrow$ Growth & $0.127 \dagger$ & 1.65 \\
\hline Manufacturing $\rightarrow$ Growth & 0.013 & 0.32 \\
\hline Profits to reinvest $\rightarrow$ Growth & $0.180 * * *$ & 4.42 \\
\hline Relationships within $\rightarrow$ Growth & 0.073 & 1.57 \\
\hline Collaborations with customers $\rightarrow$ Growth & $0.109 * *$ & 2.44 \\
\hline $\mathrm{N}=587 ; \chi^{2}(279$ d.f. $)=444.19 ; \mathrm{CFI}=0.952 ; \mathrm{TLI}=0.943 ; \mathrm{RMSEA}=0.034 ; \mathrm{R}^{2}=0.22$ & & \\
\hline
\end{tabular}




\section{Appendix}

Variables and items

Growth: $\quad$ Likert scale anchored to $1-5$

Cronbach's alpha $=0.837$

How would you rate the Primary company's current performance as compared to that of your competitors in the last three years $(2011,2012,2013)$ in terms of the following?

(1)

G_1: Growth in sales (turnover)

G_2: Growth in market share

G_3: Growth in number of employees

G_4: Growth in profitability much worse

much worse

much worse

much worse
(5)

much better

much better

much better

much better

Entrepreneurial orientation: $\quad$ Likert scale anchored to $1-5$.

Cronbach's alpha $=0.845$

Please select the choice that best describes the strategy of the Primary company:

(1)

EO_1: Under uncertain conditions, adopt

EO_2: Explore environment

EO_3: With respect to competitors

EO_4: In introducing new products or ideas

EO_5: Favor a strong

EO_6: In introducing products or technologies

EO_7: introduced any new lines of products or services in the last 5 years

EO_8: introduced any changes in products or services in the last 5 years

EO_9: Regarding competitors

EO_10: Regarding competitors a cautious posture

gradually

respond to actions which competitors initiate

tend to follow the leader

emphasis on marketing

seldom the first

not introduced any

introduced only minor changes

no effort to take the business

from competitors

seek to avoid competitive clashes
(5)

a bold posture

boldly

initiate actions to which competitors respond tend to introduce ideas/products

emphasis on R\&D/innovations

often the first

introduced many

introduced dramatic changes

aggressive and intensively

competitive

adopts a very competitive posture 